\title{
Membrane Trafficking Regulates the Activity of the Human Dopamine Transporter
}

\author{
Haley E. Melikian and Kathleen M. Buckley \\ Department of Neurobiology, Harvard Medical School, Boston, Massachusetts 02115
}

The trafficking of synaptic proteins is unquestionably a major determinant of the properties of synaptic transmission. Here, we present a detailed analysis of the downregulation and intracellular trafficking of the cocaine- and amphetamine-sensitive dopamine transporter (DAT), a presynaptic plasma membrane protein responsible for the regulation of extracellular DA concentrations. Using PC12 cells stably transfected with human DAT cDNA, we observe that phorbol ester activation of protein kinase $C(P K C)$ results in decreased transporter capacity and a parallel decrease in the amount of DAT on the cell surface that is attributable to intracellular transporter sequestration. After internalization, DAT diverges to the recycling, as opposed to the degradative, arm of the endocytic pathway. This study demonstrates, for the first time, DAT endocytosis, establishes the pathways through which DAT traffics both at steady state and in response to $\mathrm{PKC}$ activation, and suggests that DAT recycling is likely to occur.

Key words: dopamine; endocytosis; trafficking; transporter; regulation; protein kinase $C$; recycling
The temporal and spatial coordination of dopaminergic neurotransmission is achieved by striking a balance between the release and reuptake of dopamine (DA). Although a large body of work supports regulation of DA release (Langer, 1997; Nagatsu and Stjarne, 1998), far less is known about the modulation of transmitter reuptake. In the brain, clearance of extracellular DA is mediated by the high affinity DA transporter (DAT). DAT activity is critical in regulating extracellular DA levels. Indeed, elimination of DA transport either pharmacologically (Grace, 1995) or via genetic manipulation (Jones et al., 1998) results in increased extracellular DA levels and enhanced synaptic responses. DAT is a member of the gene family of $\mathrm{Na}^{+} / \mathrm{Cl}^{-}$-dependent plasma membrane transporters whose members share multiple structural features, including 12 putative transmembrane domains, multiple N-linked glycosylation sites, and putative cytoplasmic phosphorylation sites (Amara and Kuhar, 1993). In addition to DAT, the monoamine branch of the gene family includes transporters for serotonin (SERT), norepinephrine (NET), and epinephrine, all of which are potently inhibited by tricyclic antidepressants, as well as drugs of abuse, such as cocaine and amphetamines (Barker and Blakely, 1995; Nelson, 1998).

Although DAT activity is significantly attenuated by exogenously administered agents, recent reports support the hypothesis that the plasma membrane neurotransmitter transporters are subject to modulation by intrinsic cellular mechanisms. Specifically, a number of laboratories have demonstrated that highaffinity DA (Copeland et al., 1996; Huff et al., 1997; Vaughan et al., 1997; Zhang et al., 1997; Zhu et al., 1997; Pristupa et al., 1998), serotonin (Qian et al., 1997; Sakai et al., 1997; Ramamoorthy et al., 1998), NE (Apparsundaram et al., 1998a,b), and GABA

Received April 16, 1999; revised June 16, 1999; accepted June 28, 1999.

This work was supported by National Institutes of Health Grants NS27536 (K.M.B) and T32NS07112 (H.E.M.). We thank Michael Waring and Aimee Powelka for excellent technical assistance and Chester Provoda and Jennelle Richardson for helpful discussions and comments.

Correspondence should be addressed to Dr. Kathleen M. Buckley, Department of Neurobiology, Harvard Medical School, 220 Longwood Avenue, Boston, MA 02115. Copyright (C) 1999 Society for Neuroscience $0270-6474 / 99 / 197699-12 \$ 05.00 / 0$
(Corey et al., 1994; Sato et al., 1995; Quick et al., 1997; Beckman et al., 1998) transporters undergo acute downregulation in response to activation of protein kinase C (PKC). PKC-mediated transporter downregulation is reported as a decrease in the $V_{\max }$ of substrate transport, although no significant changes in substrate affinity or transport turnover rates have been reported. Moreover, cell surface labeling studies for SERT (Qian et al., 1997) and NET (Apparsundaram et al., 1998b), as well as whole-cell radioligand binding (Zhu et al., 1997) and immunofluorescent studies (Pristupa et al., 1998) for DAT, have demonstrated that monoamine transporters redistribute from the plasma membrane to an unidentified intracellular destination in response to PKC activation. These findings have caused many to speculate that membrane trafficking is the major determinant of transporter downregulation (Beckman and Quick, 1998; Blakely et al., 1998) and raise questions regarding whether common mechanisms govern the trafficking of $\mathrm{Na}^{+} / \mathrm{Cl}^{-}$-dependent transporters.

While all evidence to date supports the hypothesis that increased trafficking is the basis for PKC-mediated transporter downregulation, the molecular mechanisms responsible for putative transporter trafficking have not been elucidated. Additionally, the pathways traversed by transporters during trafficking are entirely unknown. Given that distinct molecular mechanisms govern protein trafficking within different pathways, the first step in analyzing determinants of transporter trafficking is a detailed knowledge of transporter trafficking pathways. Hence, we sought to (1) determine whether membrane trafficking was responsible for DAT downregulation and (2) define the pathways through which DAT traffics under both steady-state and regulated conditions. The results obtained demonstrate that membrane trafficking underlies PKC-mediated DAT downregulation, establish the pathway through which DAT traffics, and suggest that DAT recycling back to plasma membrane is highly likely.

\section{MATERIALS AND METHODS}

Human DAT cDNA construct

Human DAT (hDAT) cDNA cloned into pcDNA3 vector was the kind gift of Drs. Hyman Niznik and Zdenek Pristupa (University of Toronto, 
Toronto, Canada). hDAT was recovered from the pcDNA3 vector by restriction digest with HindIII/XhoI and was subcloned into pcDNA3.1(+) vector (Invitrogen, San Diego, CA) at the HindIII/XhoI site. Transfection quality cDNA was prepared using Qiagen (Valencia, CA) Maxiprep kits.

\section{Anitbodies}

A rat monoclonal antibody directed against the $\mathrm{N}$ terminus of the human dopamine transporter was the generous gift of Dr. Allan Levey (Emory University School of Medicine, Atlanta, GA). HRP-conjugated sheep anti-rat antibody was obtained from Amersham (Arlington Heights, IL), and anti-synaptophysin (SY38) and HRP-conjugated goat anti-mouse antibodies were from Boehringer Mannheim (Indianapolis, IN). Mouse monoclonal anti-transferrin receptor (TfR) antibody (H68.4) was from Zymed (San Francisco, CA) and rabbit anti-secretogranin II and rab5A antibodies were from Santa Cruz Biotechnology (Santa Cruz, CA). Mouse EEA1 antibody was from Transduction Laboratories (Lexington, KY).

\section{Cell culture and stable cell lines}

PC12 cells, acquired from American Type Culture Collection (Manassas, VA), were cultured at $37^{\circ} \mathrm{C}, 10 \% \mathrm{CO}_{2}$ in high glucose DMEM (Life Technologies, Gaithersburg, MD) supplemented with $5 \%$ horse serum (catalog \#16050-122; Life Technologies), 5\% bovine calf serum defined-supplemented (catalog \#SH30072.03; HyClone, Logan UT), 2 mM glutamine, and $100 \mathrm{U} / \mathrm{ml}$ penicillin-streptomycin. PC12 cells were stably transfected with either hDAT/pcDNA 3.1(+) or pcDNA 3.1(+) vector alone using the Lipofectamine method (Life Technologies) per the manufacturer's instructions, with slight modifications. PC12 cells were plated 2-3 d before transfection in six-well tissue culture plates. At $50-70 \%$ confluency, cells were transfected by rinsing with OPTIMEM medium (Life Technologies) and adding DNA-liposome mixture at a ratio of $12 \mu \mathrm{g}$ of DNA/2 $\mu \mathrm{l}$ of lipid per well in a final volume of $1.0 \mathrm{ml}$ of OPTIMEM. Cells were fed with complete PC12 medium $24 \mathrm{hr}$ after transfection. At $48 \mathrm{hr}$ after transfection, cells were split 1:2 into $10 \mathrm{~cm}$ plates and selected in PC12 medium containing $0.5 \mathrm{mg} / \mathrm{ml}$ G418 (Life Technologies). Selection continued until large colonies were detectable on visual inspection, at which time individuals colonies were picked and plated out into 24 -well plates. Of 55 independent clones screened by immunoblot, 37 displayed detectable levels of DAT protein and exhibited desipramine (DMI)-insensitive dihydroxyphenylethamine 3,4-[ring2,5,6,- $\left.{ }^{3} \mathrm{H}\right]\left(\left[{ }^{3} \mathrm{H}\right] \mathrm{DA}\right)$ (NEN, Boston, MA) uptake, albeit at different expression levels. In some instances, colonies were pooled to generate pooled cell lines for comparison with clonal cell lines. All vector-only transfected cells were derived using the pooling technique. Once confluent, individual cell lines were replica plated and screened for hDAT expression by immunoblotting. After selection and screening, expanded cell lines were maintained in PC12 medium supplemented with 0.2 $\mathrm{mg} / \mathrm{ml} \mathrm{G} 418$.

\section{Uptake assays}

DAT-PC12 cells were plated at a density of $4 \times 10^{4}$ cells per well on poly-D-lysine-coated 48-well plates $1 \mathrm{~d}$ before performing assays. Cells were rinsed and preincubated in $\mathrm{KRH}$ buffer $(120 \mathrm{~mm} \mathrm{NaCl}, 4.7 \mathrm{~mm}$ $\mathrm{KCl}, 2.2 \mathrm{~mm} \mathrm{CaCl}$, $1.2 \mathrm{~mm} \mathrm{MgSO}_{4}, 1.2 \mathrm{~mm} \mathrm{KH}_{2} \mathrm{PO}_{4}, 0.18 \%$ glucose, and $10 \mathrm{mM}$ HEPES, pH 7.4) at $37^{\circ} \mathrm{C}$ for $30 \mathrm{~min}$, unless otherwise indicated. For inhibition and regulation studies, antagonists and other drugs were included in the preincubation step. Assays were initiated by the addition of $\left[{ }^{3} \mathrm{H}\right] \mathrm{DA}$ and included $10^{-5} \mathrm{M}$ pargyline and $10^{-5} \mathrm{M}$ ascorbic acid (final concentrations). For single point assays, the final DA concentration was $50 \mathrm{~nm}$. For kinetic studies, increasing amounts of $\left[{ }^{3} \mathrm{H}\right] \mathrm{DA}$ were added for each DA concentration point, and nonspecific uptake was determined in parallel for each concentration point in the presence of $50 \mathrm{~nm}$ DMI and $500 \mathrm{~nm}$ nomifensine. After uptake for $10 \mathrm{~min}$ at $37^{\circ} \mathrm{C}$, assays were terminated by rapidly washing plates three times with ice-cold KRH buffer. Cells were solubilized in 1\% SDS for $15 \mathrm{~min}$ at room temperature and shaken, and accumulated radioactivity was determined by liquid scintillation counting. All assays were performed in the presence of $50 \mathrm{nM}$ DMI to block endogenous NE transporter activity. Nonspecific DA transport was defined in the presence of $50 \mathrm{nM}$ DMI and $500 \mathrm{~nm}$ nomifensine. Data analysis was performed using Microsoft (Seattle, WA) Excel and KaleidaGraph (Synergy Software, Reading, PA). Statistical analysis was performed using Instat (Graph Pad, San Diego, CA).

\section{Immunoblots and cell surface biotinylation}

DAT-PC12 cells underwent solubilization, SDS-PAGE, and immunoblot as described by Melikian et al. (1994). For quantitation, bands in the linear range of the film were scanned (Magiscan; UMAX, WillichMünchheide, Germany), and band densities were determined using ImagQuant software (Molecular Dynamics, Sunnyvale, CA).

For cell surface biotinylation, cells were rinsed four times with ice-cold PBS containing $0.1 \mathrm{mM} \mathrm{CaCl}_{2}$ and $1.0 \mathrm{~mm} \mathrm{MgCl}_{2}\left(\mathrm{PBS}^{2+}\right)$ and incubated twice with $1.0 \mathrm{mg} / \mathrm{ml} \mathrm{NHS}-\mathrm{SS}$-biotin (Pierce, Rockford, IL) for $20 \mathrm{~min}$ at $4^{\circ} \mathrm{C}$. Nonreactive biotin was quenched with $2 \times 20 \mathrm{~min}$ incubations at $4^{\circ} \mathrm{C}$ in ice-cold $\mathrm{PBS}^{2+}$ and $0.1 \mathrm{M}$ glycine. Cells were solubilized in radioimmunoprecipitation assay (RIPA) buffer (10 mM Tris, $\mathrm{pH} 7.4,150$

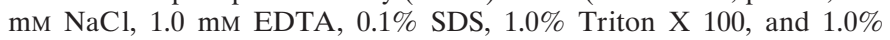
sodium deoxycholate) containing protease inhibitors (1.0 mM PMSF and $1.0 \mu \mathrm{g} / \mathrm{ml}$ each leupeptin, aprotinin, and pepstatin), and protein concentrations were determined. Biotinylated and nonbiotinylated proteins were separated from equal amounts of cellular protein by incubation with Immunopure immobilized streptavidin (Pierce) for $45 \mathrm{~min}$ at room temperature with constant mixing. Unbound proteins were precipitated with TCA (5\% final concentration) and resuspended in Laemmli sample buffer, and $\mathrm{pH}$ was adjusted with $1.0 \mathrm{M}$ Tris base. Proteins bound to streptavidin beads were eluted in Laemmli sample buffer after $4 \times 1.0 \mathrm{ml}$ washes in RIPA buffer. Biotinylated and nonbiotinylated samples were analyzed by SDS-PAGE, and immunoblotting and densitometry were performed as described above.

\section{Subcellular fractionation}

DAT-PC12 cells, grown to confluency on $15 \mathrm{~cm}$ diameter tissue culture plates, were scraped into homogenization buffer A (HBA) $(150 \mathrm{~mm}$ $\mathrm{NaCl}, 10 \mathrm{~mm}$ HEPES, pH 7.4, $1.0 \mathrm{~mm}$ EDTA, and $0.1 \mathrm{~mm} \mathrm{MgCl}_{2}$ ), pelleted $(262 \times g, 5 \mathrm{~min}$, room temperature), and resuspended in $0.5 \mathrm{ml}$ ice-cold HBA containing protease inhibitors (as above). Cells were homogenized by passing 10 times through a ball-bearing homogenizer (Berni-Tech, Palo Alto, CA) with $12 \mu \mathrm{m}$ clearance. Homogenates were centrifuged $\left(800 \times g, 10 \mathrm{~min}, 4^{\circ} \mathrm{C}\right)$, and postnuclear supernatants were assayed for protein content and were fractionated by one of the following protocols.

Large dense-core vesicles. DAT-PC12 cells were incubated in $\left[{ }^{3} \mathrm{H}\right] \mathrm{DA}$ $\left(1.0 \mu \mathrm{Ci} / \mathrm{ml}, 100 \mu \mathrm{M}\right.$ pargyline, and $100 \mu \mathrm{M}$ ascorbic acid, $\left.37^{\circ} \mathrm{C}, 16 \mathrm{hr}\right)$ to label the large dense-core vesicle (LDCV) pool. Postnuclear supernatants $(1.0 \mathrm{ml})$ were fractionated in $0.3-1.2 \mathrm{M}$ linear sucrose velocity gradients $(11 \mathrm{ml})$ in an SW41 Ti rotor (Beckman Instruments, Fullerton, CA) at $26,000 \mathrm{rpm}(83,472 \times \mathrm{g})$ for $30 \mathrm{~min}$ at $4^{\circ} \mathrm{C}$, and $12 \times 1.0 \mathrm{ml}$ fractions were taken from the top with an Autodensiflow fractionator (Labconco, Kansas City, MO). Each fraction $(200 \mu \mathrm{l})$ was reserved for liquid scintillation counting, and an additional $200 \mu \mathrm{l}$ of each fraction was TCA-precipitated and analyzed by SDS-PAGE and immunoblotting. Peak fractions containing [ $\left.{ }^{3} \mathrm{H}\right] \mathrm{DA}$ were pooled $(1.8 \mathrm{ml}$ total $)$ and underwent a second fractionation step in 0.6-1.6 $\mathrm{M}$ linear sucrose equilibrium gradients $(10.2 \mathrm{ml})$ in an SW41 rotor at 30,000 rpm $(111,132 \times \mathrm{g})$ for 16 $\mathrm{hr}$ at $4{ }^{\circ} \mathrm{C}$. Fractions $\left(1.0 \mathrm{ml}\right.$ each) were assessed for $\left[{ }^{3} \mathrm{H}\right] \mathrm{DA}$ content, DAT, and secretogranin II.

Synaptic vesicles. Postnuclear supernatant $(0.5 \mathrm{ml})$ was fractionated on $5-25 \%$ linear glycerol velocity gradient $(4.5 \mathrm{ml})$ on a $200 \mu \mathrm{l} 50 \%$ sucrose pad in an SW55 Ti rotor (Beckman Instruments) at 48,000 rpm $(218,438 \times g)$ for $45 \mathrm{~min}$ at $4^{\circ} \mathrm{C}$. The loading volume was discarded from the top of the gradient, and $16 \times 300 \mu$ fractions were taken from the top (see above). Proteins were concentrated by $5 \%$ TCA precipitation using deoxycholate $(200 \mu \mathrm{g} / \mathrm{ml})$ as a carrier. Pellets were resuspended in Laemmli SDS-PAGE sample buffer and were analyzed by SDS-PAGE and immunoblotting as described above.

Endosomes. Postnuclear supernatant $(0.5 \mathrm{ml})$ was fractionated in $10-$ $50 \%$ linear sucrose equilibrium gradients $(4.5 \mathrm{ml})$ in an SW55 Ti rotor (Beckman Instruments) at 48,000 rpm $(218,438 \times g)$ for $16 \mathrm{hr}$ at $4^{\circ} \mathrm{C}$. Fractions $(8 \times 0.6 \mathrm{ml})$ were taken from the top (see above), precipitated with TCA, and analyzed by SDS-PAGE and immunoblotting to identify DAT and the endosomal marker transferrin receptor. Sucrose concentrations for each fraction were determined by measuring the refractive index of each fraction and converting to percentage sucrose using a sucrose standard curve. 
A

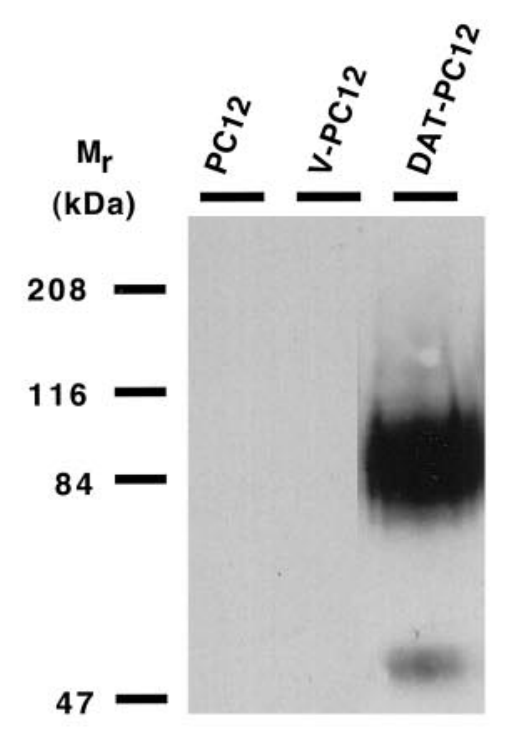

B

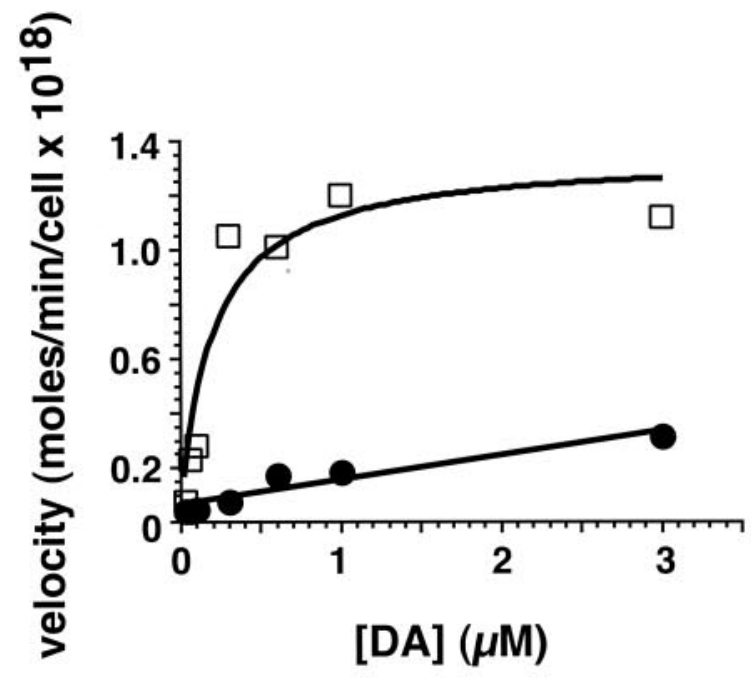

C

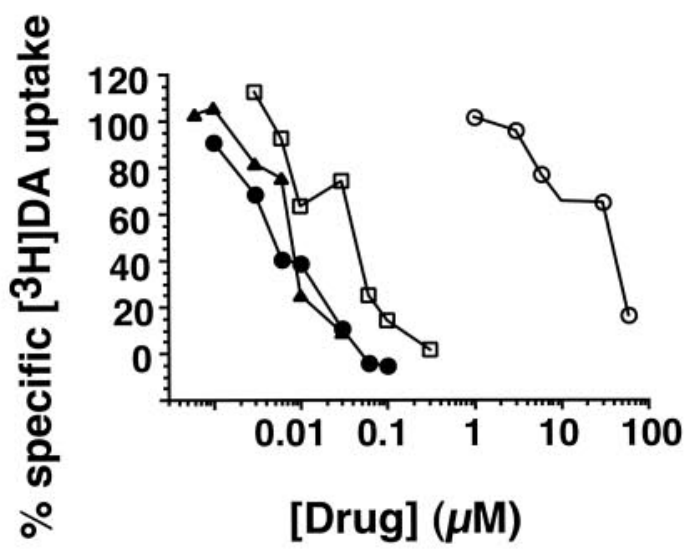

Figure 1. Stable DAT expression in DAT-PC12 cells. $A$, Immunoblot of total cell extracts $(25 \mu \mathrm{g} /$ lane $)$ from PC12 cells alone (PC12) or stably transfected with either vector $(V-P C 12)$ or hDAT (DAT-PC12) cDNAs. Blots were probed with a rat monoclonal antibody to the $\mathrm{N}$ terminus of
Internalization-2-mercaptoethanosulfonic acid protection experiments

DAT-PC12 cells were biotinylated as described above. Cells were washed four times in serum-free medium $\left(37^{\circ} \mathrm{C}\right)$, and internalization was initiated by incubating with phorbol esters, as indicated. Cells were rapidly chilled to $4^{\circ} \mathrm{C}$, and remaining cell surface biotin was removed according to the method of Schmidt et al. (1997) using 2-mercaptoethanosulfonic acid (MesNa). After MesNa treatment, cells were washed with HBA, homogenized, and fractionated in 10-50\% linear sucrose equilibrium gradients as described above. Fractions were solubilized by the addition of a $1 / 10$ volume of $10 \times$ solubilization buffer $(10 \%$ Triton X-100, $1.0 \mathrm{M}$ $\mathrm{NaCl}, 20 \mathrm{~mm}$ EDTA, and $500 \mathrm{~mm}$ Tris, $\mathrm{pH} 7.4$ ) and incubated with streptavidin beads, as described above, to isolate internalized biotinylated proteins.

\section{Organelle immunoisolation}

Postnuclear supernatants from DAT-PC12 cells were fractionated in $10-50 \%$ sucrose equilibrium gradients. The peak transferrin receptorDAT-containing fractions $(\sim 27-32 \%$ sucrose $)$ were pooled, and intact organelles containing the transferrin receptor were immunoisolated using antibody-coated magnetic beads (M-500; Dynal, Great Neck, NY). Beads were first coated with anti-mouse secondary antibody according to the manufacturer's instructions. Approximately $1.0 \mathrm{mg}$ of secondarycoated beads were incubated with $4 \mu \mathrm{g}$ of mouse anti-transferrin receptor antibody for $30 \mathrm{~min}$ at $4^{\circ} \mathrm{C}$ with mixing. This ratio of antibody to beads was determined as saturating in optimization experiments. After washing (four times for 5 min with PBS at $4^{\circ} \mathrm{C}$ ), beads were resuspended in PBS and incubated with $250 \mu \mathrm{l}$ of pooled fractions for $16 \mathrm{hr}$ at $4^{\circ} \mathrm{C}$ with mixing. Organelles remaining in the supernatant were precipitated with TCA and solubilized in Laemmli sample buffer. Magnetic beads were washed and pelleted three times with PBS for $15 \mathrm{~min}$ at $4^{\circ} \mathrm{C}$, and organelles were eluted in Laemmli sample buffer. Bead eluents and supernatants were analyzed by SDS-PAGE and immunoblotting with antibodies to the DAT and the transferrin receptor.

\section{RESULTS}

\section{Characterization of DAT-PC12 cells}

To study the regulation and trafficking of DAT in a neuroendocrine cell type, we generated a PC12 cell line in which the human DAT cDNA was stably integrated and under the transcriptional control of the cytomegalovirus promoter (DAT-PC12 cells). DAT expression was strictly dependent on transfection with hDAT cDNA and was not detected in either nontransfected or vectortransfected PC12 cells (Fig. $1 A$ ). DAT immunoreactivity was detected as a major $90 \mathrm{kDa}$ band and a lower abundant $56 \mathrm{kDa}$ band (Fig. $1 A$ ) that was a biosynthetic intermediate as determined by enzymatic deglycosylation (data not shown).

DAT-PC12 cells exhibited DAT-specific $\left[{ }^{3} \mathrm{H}\right] \mathrm{DA}$ transport in single point transport assays. DAT-specific transport was defined

\section{$\leftarrow$}

the human dopamine transporter. $B$, Saturation kinetics of DATmediated (i.e., desipramine-insensitive) $\left[{ }^{3} \mathrm{H}\right] \mathrm{DA}$ uptake in V-PC12 ( filled circles) versus DAT-PC12 (open squares) cells. Assays were performed using increasing concentrations of $\left[{ }^{3} \mathrm{H}\right] \mathrm{DA}$, and nonspecific uptake was defined in the presence of $50 \mathrm{~nm}$ desipramine (V-PC12) or $50 \mathrm{~nm}$ desipramine/500 nM nomifensine (DAT-PC12) in parallel for each $\left[{ }^{3} \mathrm{H}\right] \mathrm{DA}$ concentration point. A representative experiment of three performed is shown. $C$, Dose-response curves of DAT antagonist treatment on DATPC12 cells. Cells were treated for $30 \mathrm{~min}$ with increasing concentrations of either GBR12909 (filled circles), mazindol (filled triangles), nomifensine (open squares), or imipramine (open circles) before initiating transport with $50 \mathrm{~nm}\left[{ }^{3} \mathrm{H}\right] \mathrm{DA}$. Representative experiments are shown. All transport experiments were performed in the presence of $50 \mathrm{nM}$ DMI to eliminate contribution by the endogenous NE transporter, and nonspecific transport was defined in the presence of $50 \mathrm{nM}$ DMI and $500 \mathrm{nM}$ nomifensine. 
as $\left[{ }^{3} \mathrm{H}\right] \mathrm{DA}$ uptake in the presence of $50 \mathrm{~nm}$ DMI, added to eliminate any contribution of $\left[{ }^{3} \mathrm{H}\right] \mathrm{DA}$ uptake by endogenously expressed NET. All DAT-PC12 cell lines examined exhibited DMI-insensitive, nomifensine-sensitive $\left[{ }^{3} \mathrm{H}\right] \mathrm{DA}$ uptake (data not shown). Multiple clonal and pooled cell lines were screened, all with identical functional and biochemical profiles. Therefore, we selected a single clonal cell line, 4.27.37, for all subsequent experiments. DAT-PC12 cells exhibited a high-affinity DMIinsensitive [ $\left.{ }^{3} \mathrm{H}\right] \mathrm{DA}$ transport component with a $K_{\mathrm{m}}$ of $1.28 \pm 0.56$ $\mu \mathrm{M}(n=6)$ and a $V_{\max }$ of $6.4 \pm 2.2 \mathrm{~mol} \cdot \mathrm{min}^{-1} \cdot \operatorname{cell}^{-1}(n=6)$. In contrast, vector-transfected PC12 cells (V-PC12) did not display saturable DMI-insensitive $\left[{ }^{3} \mathrm{H}\right] \mathrm{DA}$ uptake (Fig. $1 B$ ), demonstrating the absence of any endogenous DAT in the PC12 parental cell line. DA transport was potently inhibited by several DAT antagonists, including mazindol $\left(K_{\mathrm{I}}\right.$ of $\left.10.2 \pm 3.1 \mathrm{~nm}\right)$, $\operatorname{GBR} 12909\left(K_{\mathrm{I}}\right.$ of $\left.13.9 \pm 4.8 \mathrm{nM}\right)$, and nomifensine $\left(K_{\mathrm{i}}\right.$ of $16.5 \pm$ $2.4 \mathrm{nM})$, whereas the SERT-specific antagonist imipramine demonstrated low potency $\left(K_{\mathrm{i}}\right.$ of $\left.23.1 \mu \mathrm{M}\right)($ Fig. $1 C)$ for the inhibition of DA transport. Together, these results demonstrate that DAT expressed in DAT-PC12 cells exhibits all the biochemical and functional hallmarks of DAT as previously defined in both tissue preparations (Horn, 1990) and heterologous expression systems (Lee et al., 1996) and that DAT-PC12 cells are well suited for studying DAT trafficking and regulation.

\section{DAT is downregulated in response to PKC activation}

Given the numerous reports that DAT undergoes PKC-mediated downregulation in heterologous expression systems (Huff et al., 1997; Zhang et al., 1997; Z hu et al., 1997; Pristupa et al., 1998), as well as in striatal synaptosomes (Copeland et al., 1996; Vaughan et al., 1997), we investigated whether acute DAT downregulation also occurred in DAT-PC12 cells. After treatment with the phorbol ester $\beta$ PMA at $1 \mu \mathrm{M}$ for $30 \mathrm{~min}$, we observed a $77.9 \pm$ $2.4 \%(n=3)$ decrease in the $V_{\max }$ (Fig. $\left.2 A\right)$, with no significant change in the $K_{\mathrm{m}}$ of DA transport (vehicle, $2.2 \pm 0.8 \mu \mathrm{M}$ vs $\beta$ PMA, $0.68 \pm 0.2 \mu \mathrm{M} ; n=3$ ). Cells pretreated with reserpine exhibited identical results (data not shown), ruling out the possibility that the decrease in DA transport was caused by a dilution of the specific activity of the $\left[{ }^{3} \mathrm{H}\right] \mathrm{DA}$ from release of endogenous DA stores. $\beta$ PMA downregulation was not a result of nonspecific phorbol ester effects, because the inactive analog $4 \alpha$ PMA did not downregulate DAT activity (Fig. 2B). Moreover, DAT downregulation was completely blocked when DAT-PC12 cells were coincubated with $\beta$ PMA and either the PKC inhibitor bisindolylmaleimide (BIM) (Fig. 2B) or staurosporine (data not shown). These results demonstrate that DAT undergoes acute downregulation in DAT-PC12 cells in response to $\beta$ PMA treatment and that DAT downregulation is likely to be mediated by PKC.

\section{PKC activation results in a loss of cell surface DAT}

Numerous demonstrations of decreased transporter kinetics in response to $\beta$ PMA treatment raise questions regarding the cellular mechanisms underlying DAT downregulation. A decrease in the $V_{\text {max }}$ of DA transport in response to $\mathrm{PKC}$ activation may reflect either a decrease in transporter density at the cell surface or a decrease in transport turnover rates. To distinguish between these two possibilities, we used cell surface biotinylation to examine the cell surface population of DAT after either vehicle or $\beta$ PMA treatment. As revealed in Figure $3, A$ and $B, 37.3 \pm 7.5 \%$ $(n=4)$ of total DAT is biotinylated after vehicle treatment. In contrast, after $\beta$ PMA treatment, the amount of biotinylated DAT
A

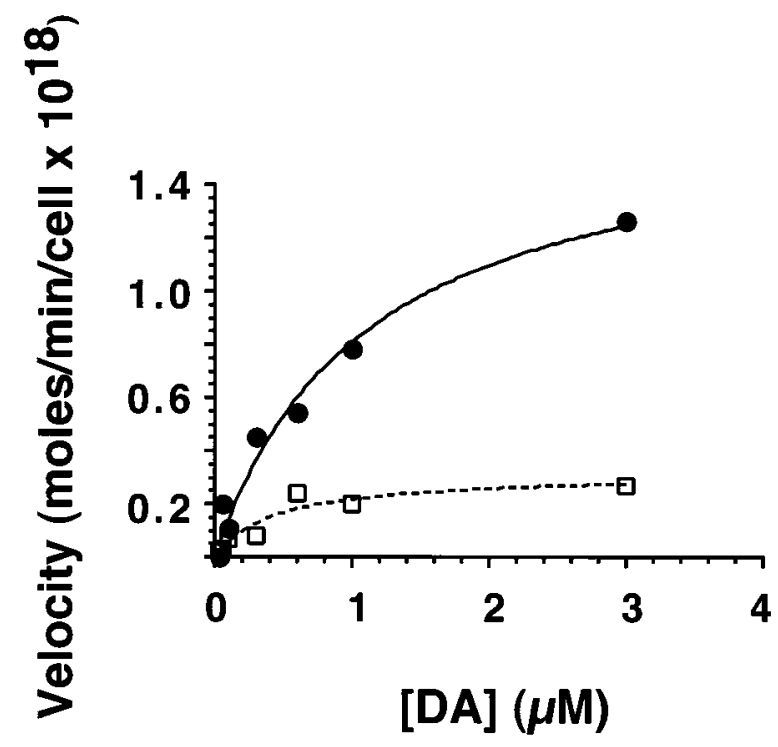

B

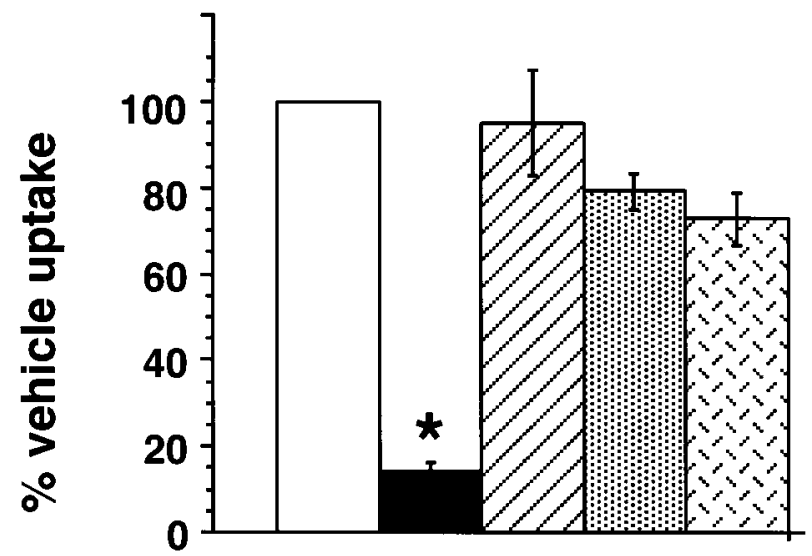

Figure 2. PKC activation results in DAT downregulation in DAT-PC12 cells. $A$, Saturation kinetics of $\left[{ }^{3} \mathrm{H}\right] \mathrm{DA}$ uptake in DAT-PC12 cells pretreated for $30 \mathrm{~min}$ with either vehicle (filled circles) or $1.0 \mu \mathrm{M} \beta \mathrm{PMA}$ (open squares). Assays were performed using increasing concentrations of $\left[{ }^{3} \mathrm{H}\right] \mathrm{DA}$, and nonspecific uptake was defined in parallel for each $\left[{ }^{3} \mathrm{H}\right] \mathrm{DA}$ concentration point. A representative experiment is shown. $B$, Specificity of DAT downregulation after 30 min pretreatment with vehicle (open bar), $1.0 \mu \mathrm{M} \beta$ PMA ( filled bar), $1.0 \mu \mathrm{M} 4 \alpha$ PMA (hatched bar), $1.0 \mu \mathrm{M}$ BIM (shaded bar), or $1.0 \mu \mathrm{M}$ each $\beta$ PMA and BIM (speckled bar). Assays were performed using $1.0 \mu \mathrm{M}\left[{ }^{3} \mathrm{H}\right] \mathrm{DA}$. Values are expressed mean \pm SEM and are averages from three independent experiments. ${ }^{*} p<0.01$ compared with $4 \alpha \mathrm{PMA}, \mathrm{BIM}$, and $\beta \mathrm{PMA}$ and BIM as determined by ANOVA $(F=24.207)$ and Dunnett's post hoc analysis. All assays were performed in the presence of $50 \mathrm{nM}$ DMI to eliminate contribution by the endogenous NE transporter. Nonspecific uptake was defined in the presence of $50 \mathrm{~nm}$ DMI and $500 \mathrm{~nm}$ nomifensine. 


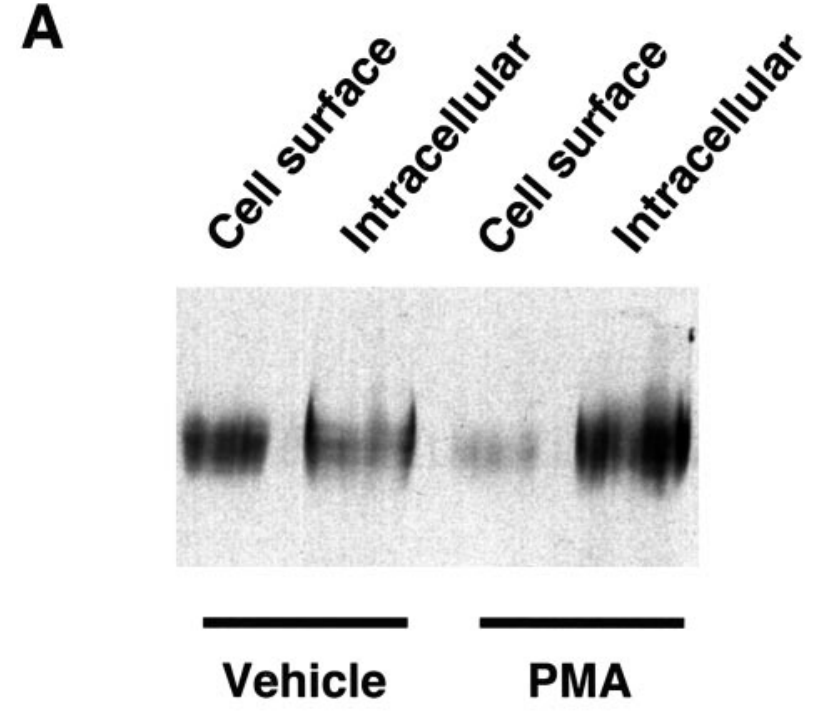

B

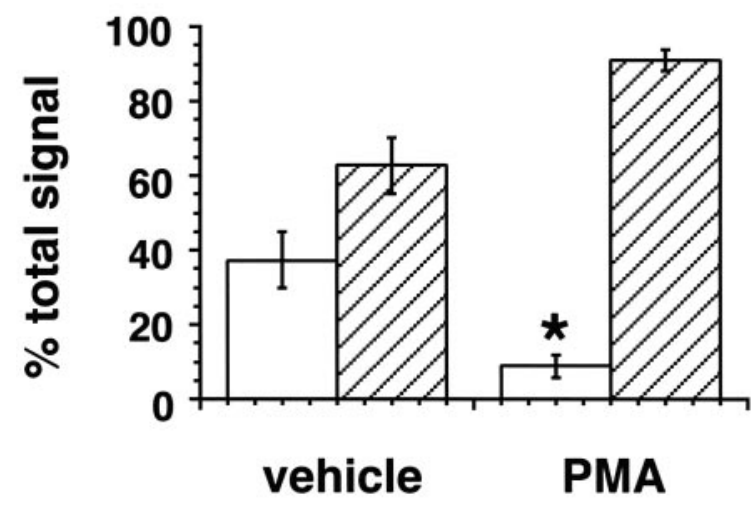

Figure 3. PKC activation results in DAT redistribution from the cell surface to an intracellular pool. $A$, Steady-state biotinylation of DATPC12 cells after 30 min treatment with either vehicle or $1.0 \mu \mathrm{M}$ PMA. Biotinylated (cell surface) and nonbiotinylated (intracellular) proteins were separated with streptavidin beads and analyzed by immunoblot with a DAT-specific antibody as described in Materials and Methods. A representative immunoblot is shown. B, Quantitation of DAT-PC12 cell biotinylation. Immunoblots of biotinylated (cell surface; open bars) and nonbiotinylated (intracellular; hatched bars) proteins were scanned and quantitated using ImageQuant software. ${ }^{*} p<0.05$, significant difference compared with vehicle-treated cells; unpaired Student's $t$ test; $n=4$.

is reduced to $8.8 \pm 2.9 \%$ of the total DAT $(n=4)$. This corresponds to a $76.3 \%$ reduction in the amount of cell surface DAT and is consistent with the magnitude of the decrease in $V_{\max }$ after $\beta$ PMA treatment. Total DAT signals were not significantly reduced after $\beta$ PMA treatment $(110.5 \pm 10.8 \%$ of vehicle; $n=4)$, suggesting that reduction in cell surface DAT is not caused by degradation. Together, these data indicate that activation of PKC results in a redistribution of DAT from the cell surface to intra- cellular compartments and that the loss of DAT from the plasma membrane is responsible for the decrease in $V_{\max }$ observed after $\beta$ PMA treatment.

\section{Intracellular DAT colocalizes with endosomal markers}

Examination of the distribution of DAT in DAT-PC12 cells demonstrated that, at steady state, a substantial amount $(62.7 \pm$ $7.4 \%$ ) of mature DAT protein is intracellular. Given that different types of intracellular organelles are subject to distinct trafficking mechanisms, we sought to determine the identity of the DAT-containing intracellular compartment. To this end, we performed a series of subcellular fractionations on postnuclear supernatants $(800 \times g)$ prepared from DAT-PC12 cells and compared the fractionation of DAT with known cellular organelle markers.

First, we examined the population of LDCVs using a two-stage subcellular fractionation method. DAT-PC12 cells were preloaded with $\left[{ }^{3} \mathrm{H}\right] \mathrm{DA}$ to label the LDCVs. Analysis of the first fractionation (0.3-1.2 $\mathrm{m}$ sucrose velocity gradient) revealed that, whereas preloaded $\left[{ }^{3} \mathrm{H}\right] \mathrm{DA}$ and the LDCV marker secretogranin II (data not shown) colocalized to fractions 5-7, DAT segregated into two peaks that were distinct from the secretogranin II$\left[{ }^{3} \mathrm{H}\right] \mathrm{DA}$ peak (Fig. $4 A$ ). Further fractionation of the secretogranin II- $\left[{ }^{3} \mathrm{H}\right]$ DA peak fractions on $0.6-1.6 \mathrm{~m}$ sucrose equilibrium gradients also revealed that DAT migrates at a density distinct from that of LDCVs (Fig. $4 B$ ) and suggests that the majority of DAT is not localized to this organelle.

We also examined the population of synaptic vesicles (SVs) by fractionation in 5-25\% glycerol velocity gradients, a method known to identify SVs in PC12 cells (Clift-O'Grady et al., 1990). As illustrated in Figure 5, whereas SVs peak in fractions 4-9, the majority of DAT peaked in fractions 13-16, suggesting that the majority of intracellular DAT is not localized to SVs.

Finally, we examined the distribution of DAT in $10-50 \%$ sucrose equilibrium gradients compared with markers of the endocytic pathway. After endocytosis, proteins are targeted to the early, or sorting, endosome (SE), characterized by the molecular markers EEA1 and rab5 (Clague, 1998). Proteins destined for recycling back to the plasma membrane, such as the transferrin receptor, traffic from the SE to the pericentriolar endosomal recycling compartment (ERC), characterized by the presence of the majority of intracellular TfR. Proteins destined for degradation [e.g., epidermal growth factor (EGF) receptor] exit the endosomal pathway at the SE and traffic through the late endosome-lysosome pathway (Sorkin, 1998) (see Fig. 10). DAT immunoreactivity peaked precisely with that of the TfR at $29 \pm$ $0.6 \%$ sucrose $(n=5)$, whereas rab5A and EAA1 fractionated at a significantly distinct density (unpaired Student's $t$ test; $p<.005$ ) at a sucrose concentration of $22.4 \pm 0.4 \%$ sucrose $(n=3)$ (Fig. 6). Thus, it appears that, at steady state, the majority of intracellular DAT cofractionates with the TfR-positive ERC but not the rab5A-EEA1-positive SE.

Comigration of DAT with the TfR suggested that DAT might reside in the ERC. Alternatively, whereas TfR resides in the ERC, DAT may reside in a distinct vesicle of similar density. To distinguish between these possibilities, we pooled the peak DAT-TfR-immunopositive fractions and isolated intact organelles with antibodies to the TfR, followed by immunoblot for the presence of DAT. Organelle immunoisolation with anti-TfR antibodies coprecipitated nearly all of the DAT present, whereas a control antibody did not immunoprecipitate TfR or appreciable 
A

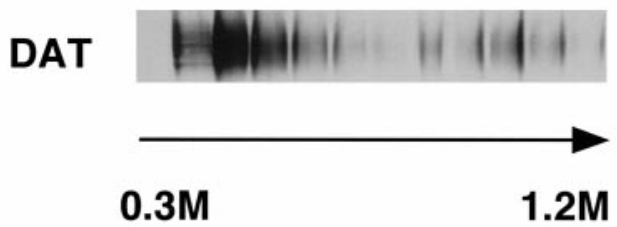

[sucrose]

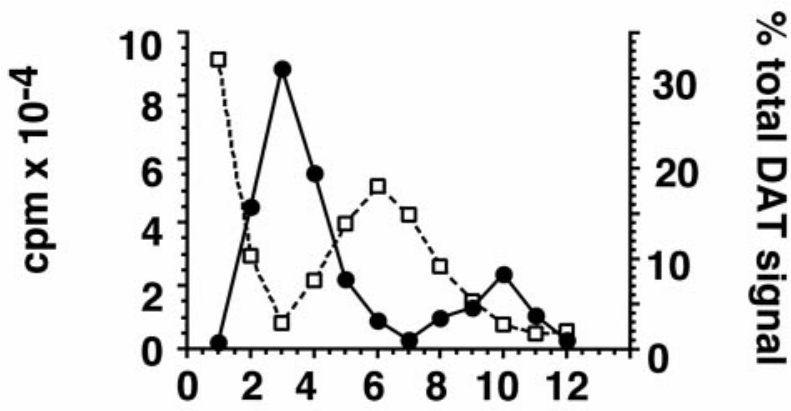

Fraction \#
B

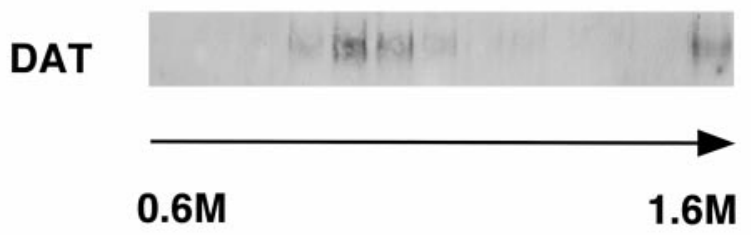

[sucrose]

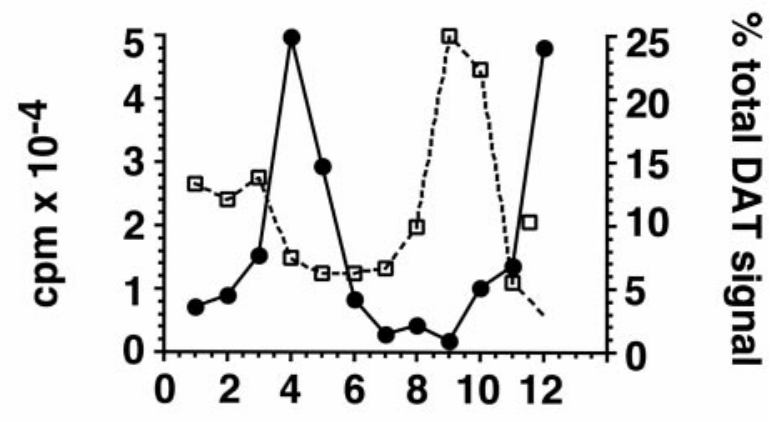

Fraction \#

Figure 4. DAT does not colocalize with large dense-core vesicles in DAT-PC12 cells. $A, B$, Large dense-core vesicles fractionation. [ $\left.{ }^{3} \mathrm{H}\right] \mathrm{DA}-\mathrm{labeled}$ DAT-PC12 cells were fractionated in $0.3-1.2 \mathrm{M}$ sucrose velocity gradients, $(A)$ followed by fractionation of peak [ $\left.{ }^{3} \mathrm{H}\right] \mathrm{DA}-\mathrm{containing}$ fractions on $0.6-1.6$ M sucrose equilibrium gradients $(B)$. Top, Fractions were analyzed for DAT content by immunoblot. Bottom, Fractionation profile of DAT signal ( filled circles) and $\left[{ }^{3} \mathrm{H}\right] \mathrm{DA}$ (in counts per minute; open squares). A representative experiment of two performed is shown.

amounts of DAT (Fig. 7). Additionally, EEA1 failed to coprecipitate with the TfR (data not shown), consistent with the DATTfR compartment being distinct from the EEA1-positive SE. These data demonstrate that DAT and TfR are present in the same intracellular vesicles and indicate that, at steady state, DAT is enriched in the ERC.

\section{DAT is targeted to the recycling endosome in response to PKC activation}

ERC-localized DAT may be involved in DAT trafficking during downregulation. Alternatively, endosomal DAT may serve a trafficking function distinct from DAT sequestration after PKC activation. To distinguish between these possibilities, we directly examined the internalization pathway through which DAT traffics during steady state and after PKC activation. First, DAT-PC12 cells were biotinylated at $4^{\circ} \mathrm{C}$ with NHS-SS-biotin to label the cell surface population of proteins. Cells were rapidly warmed to $37^{\circ} \mathrm{C}$ and were incubated with either vehicle or $\beta$ PMA for $30 \mathrm{~min}$ at $37^{\circ} \mathrm{C}$ to initiate DAT internalization. Next, cells were rapidly chilled to $4^{\circ} \mathrm{C}$ to arrest endocytosis, and any remaining cell surface biotin was removed by treating with the cell-impermeant reducing agent $\mathrm{MesNa}$. Under these conditions, only proteins that were present on the cell surface and were subsequently internalized would remain biotinylated. Cells were then fractionated on
$10-50 \%$ sucrose equilibrium gradients, and internalized biotinylated proteins were isolated with streptavidin beads. Using this method, only DAT that arose from the cell surface (i.e., biotinylated) and accumulated intracellularly (i.e., MesNa protected) would be identified.

As seen in Figure 8, during vehicle treatment, biotinylated DAT cofractionated with biotinylated transferrin receptor peak, demonstrating basal endocytosis of TfR and DAT. $\beta$ PMA treatment resulted in a robust increase in the amount of internalized DAT $(243 \pm 15.1 \%$ over vehicle treatment; $n=3)$. Moreover, internalized DAT accumulated in the TfR-positive ERC and did not shift to some other compartment. The cofractionation of internalized DAT and TfR likely represents DAT trafficking to the ERC. Alternatively, DAT may internalize and accumulate in an organelle of similar density but physically distinct from the ERC. To further characterize the compartment in which DAT accumulates during $\beta$ PMA treatment, we treated DAT-PC12 cells with $\beta$ PMA $(1.0 \mu \mathrm{M}, 30 \mathrm{~min})$, fractionated postnuclear supernatants in $10-50 \%$ sucrose equilibrium gradients, and performed organelle immunoisolation on pooled DAT-positive fractions. As seen in Figure 9, immunoisolation of organelles with an antibody directed against the TfR isolated the majority of TfR $(>81 \%)$, as well as the majority of DAT $(>88 \%)$, consistent with the accumulation of DAT in the TfR-positive ERC during PMA- 


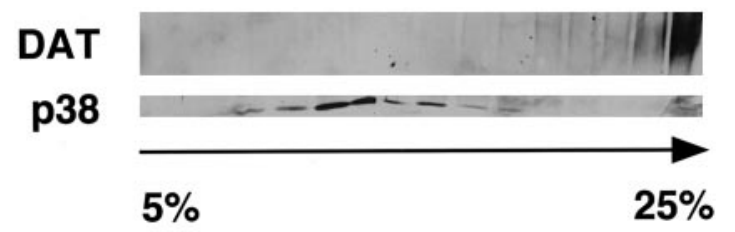

[glycerol]

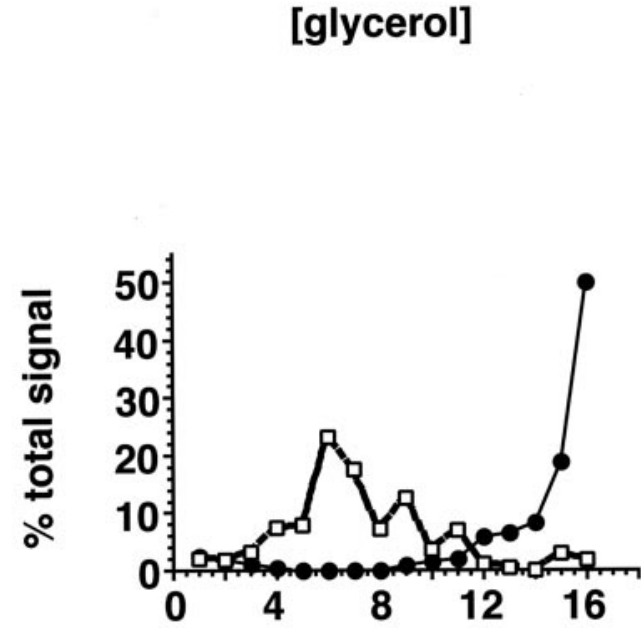

Fraction \#

Figure 5. DAT does not colocalize with synaptic vesicles in DAT-PC12 cells. DAT-PC12 cells were homogenized and fractionated in 5-25\% glycerol velocity gradients as described in Materials and Methods. Top, Immunoblot of fractions with antibodies to DAT and the synaptic vesicle marker p38 (synaptophysin). Bottom, Quantitation of DAT ( filled circles) and p38 (open squares) signals detected in each fraction. The peak of DAT immunoreactivity is localized to the bottom of the gradient, whereas synaptic vesicles migrate to fractions $5-8$ of the gradient. A representative experiment is shown of three performed.

induced downregulation. These results demonstrate that DAT (1) undergoes endocytosis under basal conditions and (2) is targeted to the TfR-positive ERC under steady-state conditions, as well as during PKC-mediated downregulation.

\section{DISCUSSION}

Membrane trafficking in neurons is fundamental to a number of key regulatory events, including synaptic vesicle recycling, desensitization of G-protein-coupled receptors (Cao et al., 1998; Vickery and von Zastrow, 1999), and attenuation of signaling through receptor tyrosine kinases (Sorkin, 1998). Moreover, recent studies implicate endocytic trafficking in ionotropic glutamate receptor downregulation (Lissin et al., 1999) and suggest that trafficking may play a potential role in neuronal plasticity. Given recent reports that DAT undergoes PKC-mediated downregulation, we tested the hypothesis that endocytic trafficking underlies DAT downregulation and sought to define the pathway(s) through which endocytic DAT travels.

To study DAT regulation and trafficking in a homogeneous neuroendocrine preparation, we generated a stable PC12 cell line expressing human DAT cDNA. DAT-PC12 cells exhibited all of the hallmarks of DA transport, with kinetic constants and antagonist potencies in excellent agreement with those obtained in both striatal membranes (Horn, 1990) and heterologous expression systems (Lee et al., 1996). Given the notorious heterogeneity
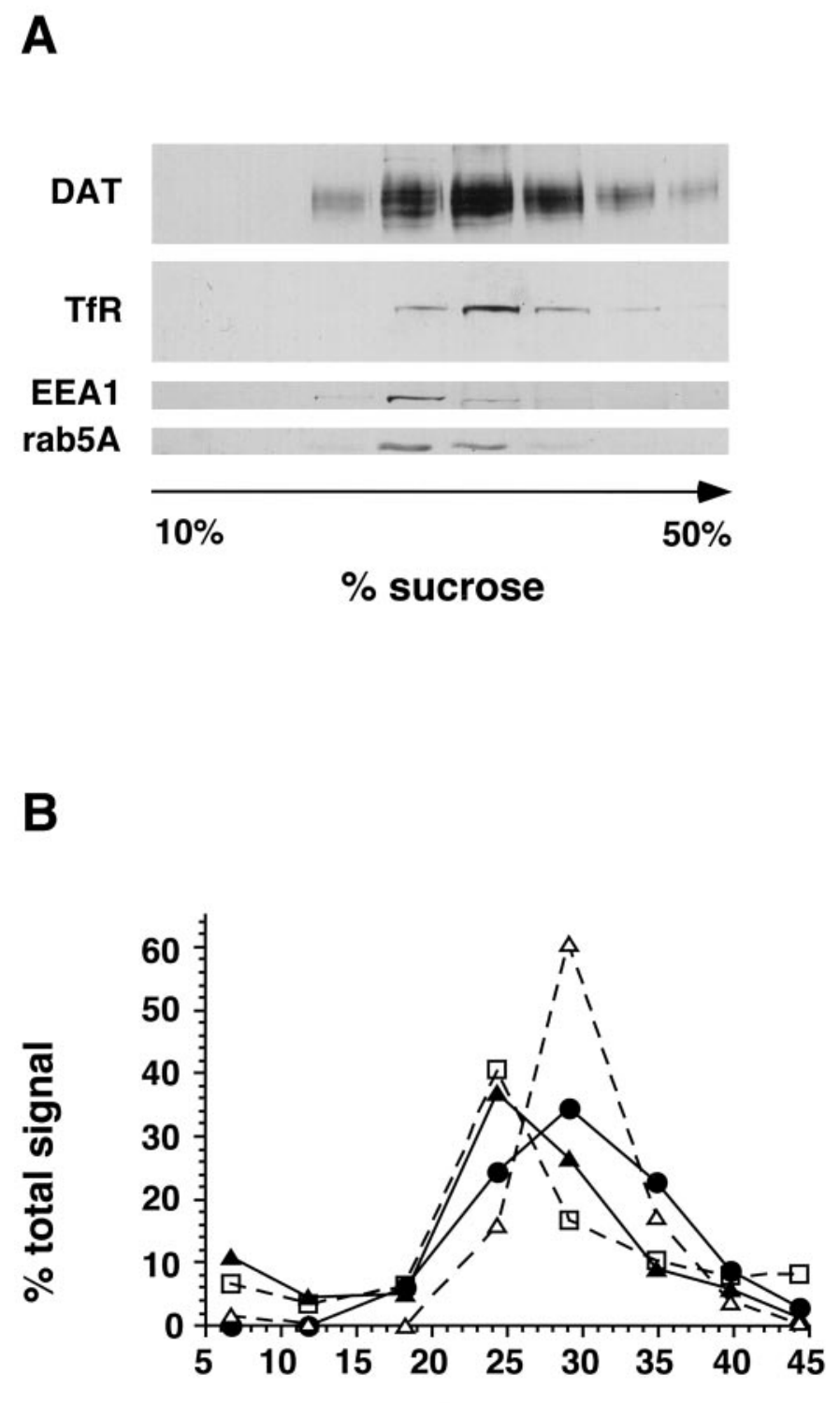

$\%$ sucrose

Figure 6. DAT and TfR cofractionate on sucrose equilibrium gradients. DAT-PC12 cells were homogenized and fractionated on $10-50 \%$ sucrose equilibrium gradients as described in Materials and Methods. Fractions were TCA-precipitated and analyzed by SDS-PAGE (10\%) and immunoblot. $A$, Immunoblot probing with antibodies for the human DAT, TfR, rab5A, and EEA1. B, Quantitation of 10-50\% sucrose equilibrium gradient probed for DAT ( filled circles), TfR (open triangles), rab5A ( filled triangles), and EEA1 (open squares). DAT and TfR colocalize at $29 \pm$ $0.6 \%$ sucrose $(n=5)$, whereas rab5A and EAA1 fractionated at a significantly distinct density (unpaired Student's $t$ test; $p<0.005$ ) at a sucrose concentration of $22.4 \pm 0.4 \%$ sucrose $(n=3)$. Blots were scanned, and band densities were determined using ImageQuant software as described in Materials and Methods. Experiments were performed three to six times with essentially identical results. A representative example is shown.

of PC12 cells, we screened numerous clonal and pooled cell lines to confirm that cell lineage or DAT expression levels did not affect DAT function, biosynthesis, or downregulation. Regardless of which clonal line was studied, no variation in DAT electrophoretic mobility, transport activity, or susceptibility to $\beta$ PMAinduced downregulation was detected. 

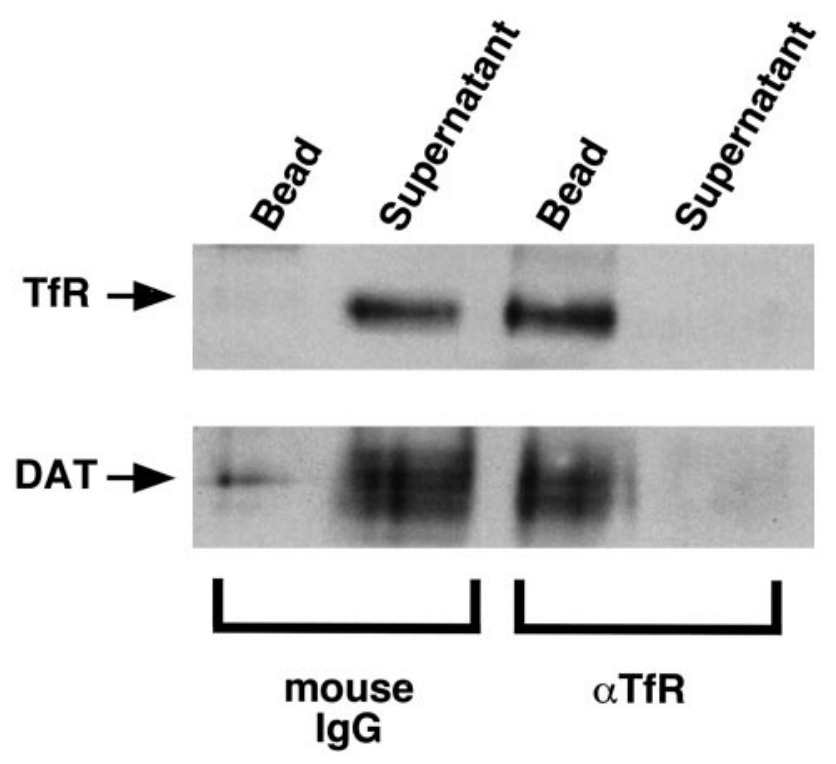

Figure 7. DAT and TfR are localized to the same organelle at steady state. Organelle immunoisolation from DAT-PC12 cells. DAT-PC12 cells were homogenized and fractionated in $10-50 \%$ sucrose equilibrium gradients. Peak DAT-TfR fractions were pooled, and intact organelles were immunoisolated using magnetic beads coated with either a negative control antibody (mouse $\operatorname{Ig} G$ ) or a monoclonal antibody directed against the human transferrin receptor $(\alpha T f R)$. Bead eluents and supernatants were analyzed by $10 \%$ SDS-PAGE and were immunoblotted with antibodies directed against either DAT or TfR. The majority of DAT and the $\mathrm{TfR}$ are precipitated by antibodies to the $\mathrm{TfR}$, while both proteins remain in the supernatant when control beads are used.

After fully characterizing the DAT-PC12 cell line, we first investigated whether DAT function was modulated in response to $\beta$ PMA treatment. Thirty minute treatment with $1 \mu \mathrm{M} \beta \mathrm{PMA}$ resulted in a robust transporter downregulation, observed as a $77.9 \pm 2.4 \%$ decrease in transporter $V_{\max }$ (Fig. $2 A$ ). The magnitude of this decrease is consistent with findings from striatal synaptosomes (Copeland et al., 1996; Vaughan et al., 1997) and oocytes (Zhu et al., 1997), as well as in C6 glioma (Zhang et al., 1997), LLC-PK 1 (Huff et al., 1997), COS, and Sf9 (Pristupa et al., $1998)$ cells. Moreover, coincubation with $\beta$ PMA and either staurosporine (data not shown) or BIM (Fig. $2 B$ ) blocked the effects of $\beta \mathrm{PMA}$, suggesting that $\beta \mathrm{PMA}$-induced DAT downregulation requires activation of PKC. The effects of PKC activation on DA transport were not caused by global alterations in membrane trafficking or ion gradients, as $\mathrm{Na}^{+}$-dependent $\left[{ }^{3} \mathrm{H}\right]$ alanine transport was not affected by PMA treatment (data not shown). Whereas PKC activation is clearly involved in DAT downregulation, the specific role of PKC in DAT downregulation has not yet been determined. Phorbol ester-mediated PKC activation also results in phosphorylation of DAT (Huff et al., 1997; Vaughan et al., 1997) and SERT (Ramamoorthy et al., 1998); however, direct phosphorylation of DAT or SERT by PKC has not been demonstrated, raising the possibility that PKC may mediate transporter phosphorylation and/or downregulation via recruitment of yet unidentified downstream effectors. Indeed, recent reports suggest that cAMP-dependent protein kinase may play a role in DAT (Batchelor and Schenk, 1998), as well as SERT and NET (Jayanthi and DeFelice, Society for Neuroscience, 1998) regulation and also that $\mathrm{Ca}^{2+}$-dependent pathways may also contribute to transporter modulation (Uchida et al., 1998).

A decrease in $V_{\max }$ of DA transport suggests that DAT down- regulation may reflect decreased cell surface expression of DAT. Transporter internalization has been demonstrated recently for both SERT (Qian et al., 1997) and NET (Apparsundaram et al., 1998b). Immunofluorescent examination of DAT expressed in COS and Sf9 cells suggests that DAT redistributes in response to kinase activation (Pristupa et al., 1998); however, a biochemical analysis of DAT redistribution has not been performed to date. Moreover, if DAT is sequestered during downregulation, neither the identity of the intracellular compartment harboring DAT nor the pathways traversed by DAT are established. To examine the plasma membrane pool during DAT downregulation, we performed cell surface biotinylation on DAT-PC12 cells after either vehicle or $\beta$ PMA treatment. As seen in Figure $3 A, \beta$ PMA treatment resulted in a significant shift in the distribution of DAT from the cell surface to an intracellular location. The loss of DAT from the cell surface could not be explained by degradation, because there was not a significant loss in the total amount of DAT signal per experiment. Therefore, we conclude that decreased $V_{\max }$ of DA transport in response to $\mathrm{PKC}$ activation is the result of sequestration of DAT from the cell surface an intracellular compartment(s) whose identity is not known.

DAT-PC12 cell biotinylation also revealed that, even under vehicle-treated conditions, a substantial proportion of DAT is intracellular $(62.7 \pm 7.4 \% ; n=4)$. Ultrastructural studies investigating the subcellular localization of DAT in the rat brain have revealed an intracellular DAT pool in substantia nigra (Nirenberg et al., 1996; Hersch et al., 1997), VTA (Nirenberg et al., 1997), and their projections. To biochemically identify the compartment containing DAT, we used subcellular fractionation to characterize which intracellular organelles harbor DAT. DAT did not appear to be enriched in large dense-core vesicles (Fig. 4A,B), nor was DAT present in synaptic vesicles (Fig. 5). Interestingly, a recent report from Renick et al. (1999) demonstrated enrichment of the $\mathrm{Na}^{+} / \mathrm{Cl}^{-}$-dependent proline transporter, but not DAT, in synaptic vesicles isolated from rat brain, suggesting that the subcellular targeting of DAT in DAT-PC12 cells is consistent with that found in the brain.

Fractionation of DAT-PC12 cells in sucrose equilibrium gradients and intact organelle immunoisolation demonstrated that, at steady state, DAT colocalizes with the transferrin receptor in the ERC but not with rab5A and EAA1 in the SE (Fig. 7). Detection of TfR in the ERC but not the SE is entirely consistent with its rapid exit from the SE (Dunn et al., 1989) but slower exit from the ERC (McGraw et al., 1987). Localization of DAT to the ERC at steady state does not necessarily mean that DAT is targeted to the ERC during PKC-mediated downregulation. Alternatively, ERC-localized DAT may be involved in some other trafficking event unrelated to transporter downregulation. To determine whether PKC activation resulted in DAT internalization to the ERC, we examined the destination of cell surface DAT after $\beta$ PMA treatment. As seen in Figure 8, $\beta$ PMA treatment resulted in a striking increase in the amount of biotinylated DAT present in the TfR-positive ERC, suggesting that the DAT is targeted to this organelle after internalization and that the DAT-positive organelle is, indeed, endocytic. Moreover, after PMA treatment, the majority of DAT colocalizes to TfR-positive ERCs as determined by organelle immunoisolation (Fig. 9). To the best of our knowledge, this is the first identification of the endocytic pathway and organelle used by a $\mathrm{Na}^{+} / \mathrm{Cl}^{-}$-dependent neurotransmitter transporter. The accumulation of DAT in the recycling endosome in response to PKC activation could be caused by an increase in the endocytic rate or, conversely, a decrease in the exocytic rate 


\section{A}

\section{Dopamine Transporter}

\section{Vehicle}

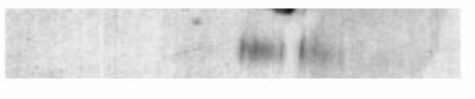

PMA

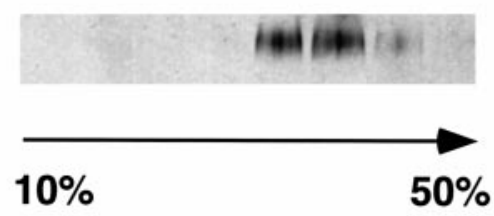

[sucrose]

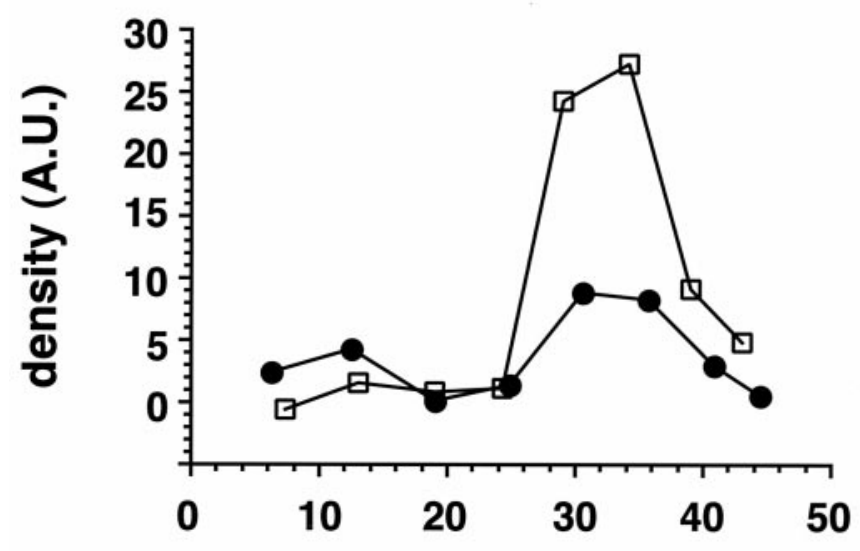

$\%$ sucrose

\section{Transferrin Receptor}

\section{Vehicle}
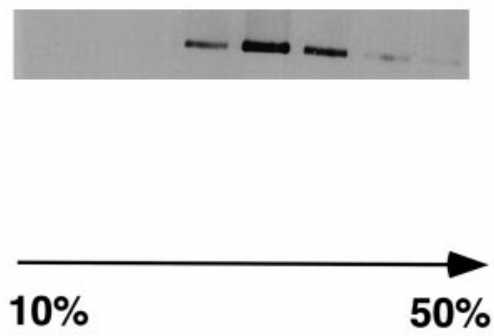

[sucrose]

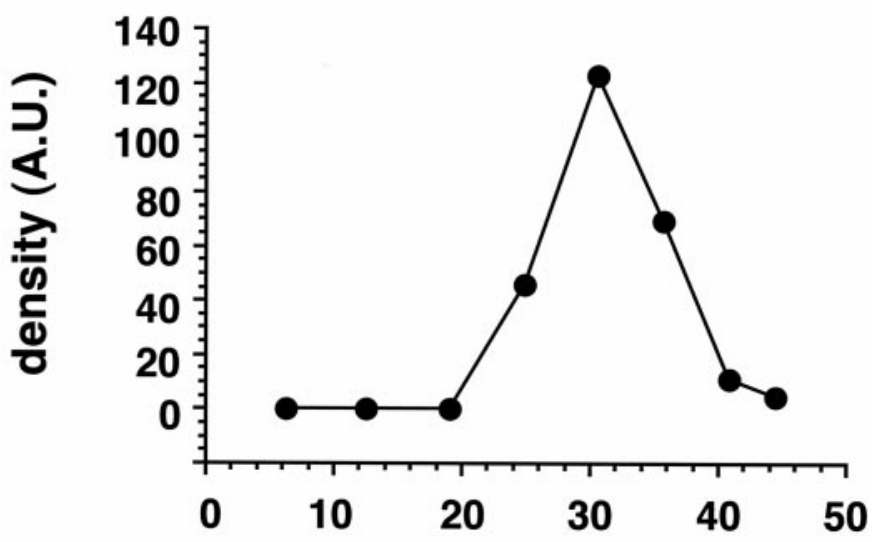

$\%$ sucrose

Figure 8. DAT internalizes to the endosomal recycling compartment in response to phorbol ester treatment. DAT-PC12 cells were biotinylated at $4^{\circ} \mathrm{C}$, warmed to $37^{\circ} \mathrm{C}$, and treated with either vehicle (filled circles) or $1.0 \mu \mathrm{M} \beta \mathrm{PMA}$ (open squares) for 30 min at $37^{\circ} \mathrm{C}$ to initiate endocytosis. Cells were rapidly chilled to $4^{\circ} \mathrm{C}$, and noninternalized biotin was released from the cell surface by treatment with $10 \mathrm{~mm}$ MesNa as described in Materials and Methods. Cells were homogenized and fractionated in 10-50\% sucrose equilibrium gradients, and organelles were solubilized. Biotinylated proteins were isolated from each fraction with streptavidin beads and analyzed by 10\% SDS-PAGE and immunoblot. Top, Immunoblot of internalized DAT and TfR after treatment with vehicle or $1.0 \mu \mathrm{M} \beta$ PMA. Bottom, Quantitation of DAT and TfR immunoreactivity after treatment with either vehicle ( filled circles) or $1.0 \mu \mathrm{M}$ PPMA (open squares). A representative experiment of three independent experiments is shown.

of DAT. Ongoing studies in the laboratory should prove illuminating in this regard.

The confirmation of transporter endocytosis raises a number of questions. What is the cellular fate of endocytosed transporters? Other plasma membrane proteins subject to endocytosis can meet with a variety of fates. For example, the receptor tyrosine kinases can recycle back to the cell surface, traffic to degradative organelles (Mellman, 1996; Sorkin, 1998) such as lysosomes, or, in the case of the NGF receptor TrkA, form a novel signaling organelle (Grimes et al., 1996, 1997). A number of receptors, such 


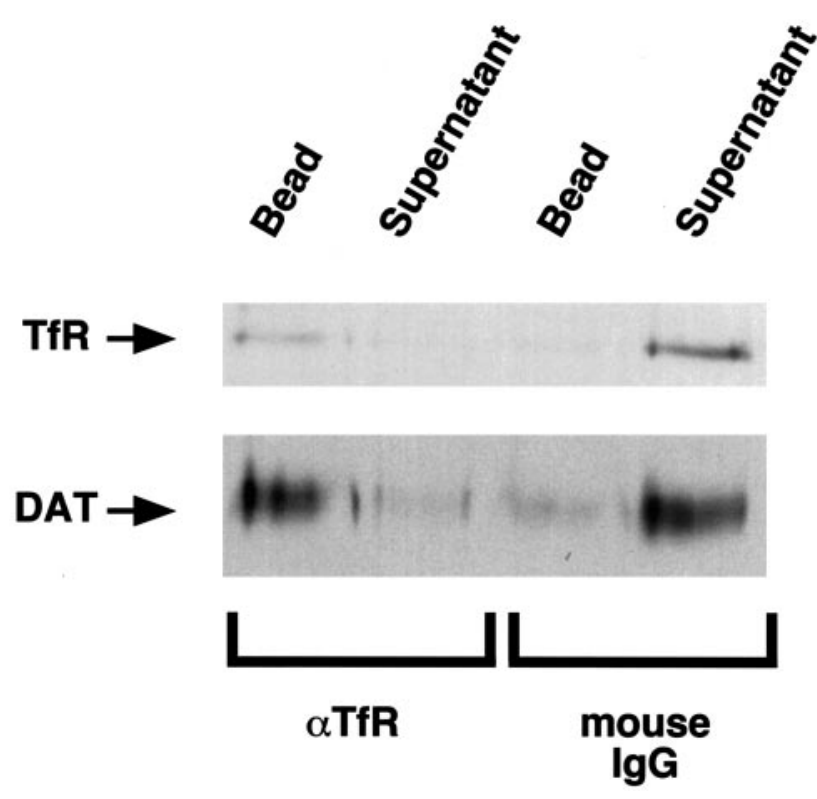

Figure 9. After PMA treatment, DAT is localized to the ERC. Organelle immunoisolation from DAT-PC12 cells. After treatment with 1.0 $\mu \mathrm{M}$ PMA for $30 \mathrm{~min}$ at $37^{\circ} \mathrm{C}$, DAT-PC12 cells were homogenized and fractionated in $10-50 \%$ sucrose equilibrium gradients. Peak DAT-TfR fractions were pooled, and intact organelles were immunoisolated using magnetic beads coated with either a negative control antibody (mouse $\operatorname{IgG}$ ) or a monoclonal antibody directed against the human transferrin receptor $(\alpha T f R ; H 68.4)$. Bead eluents and supernatants were analyzed by $10 \%$ SDS-PAGE and were immunoblotted with antibodies directed against either DAT or TfR. After PMA treatment, the majority of DAT and the $\mathrm{TfR}$ are precipitated by antibodies to the $\mathrm{TfR}$, while both proteins remain in the supernatant when control beads are used.

as the transferrin and low-density lipoprotein receptors, undergo multiple rounds of ligand-induced internalization and recycling back to the plasma membrane (Mellman, 1996; Sorkin, 1998). To date, it is not understood whether endocytosed DAT recycles back to the plasma membrane. However, the targeting of DAT to the ERC suggests that DAT recycling is likely. Moreover, the movement of DAT, presumably through the SE (Fig. 9), to the ERC as opposed to the late endosomal-degradatory pathway suggests that PKC-mediated DAT internalization does not result in chronic DAT depletion; rather, DAT internalization is likely to result in short-term, recoverable downregulation.

What intrinsic-extrinsic molecular factors govern transporter trafficking? Although it is clear that many of the $\mathrm{Na}^{+} / \mathrm{Cl}^{-}$dependent neurotransmitter transporters are subject to downregulation, it is entirely unknown whether the same cellular mechanisms control membrane trafficking of transporter homologs. Hence, although it is tempting to suggest that the DAT trafficking pathways we have identified will be applicable for all of the $\mathrm{Na}^{+} / \mathrm{Cl}^{-}$-dependent transporters, it is highly possible that each homolog may present exciting differences corresponding to their individual structural divergence. Indeed, recent trafficking studies examining internalization of DA receptor subtypes (Vickery and von Zastrow, 1999) suggest that multiple mechanisms may differentially govern the internalization of homologous plasma membrane proteins. Moreover, studies performed in polarized epithelial cells demonstrate that transporter homologs are differentially targeted to cellular domains (Ahn et al., 1996; Gu et al., 1996). Finally, are there physiologically relevant mechanisms

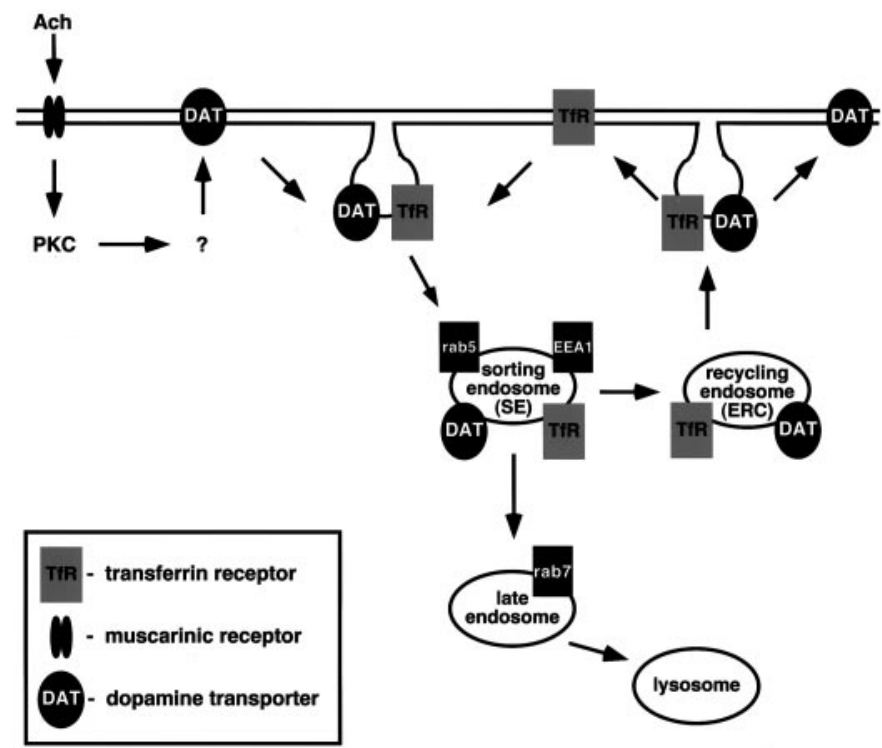

Figure 10. Model for DAT endocytic trafficking. DAT constitutively recycles between the plasma membrane and intracellular endosomal compartments. Activation of PKC via cell surface receptors (e.g. muscarinic acetylcholine receptors) results in an accumulation of DAT in the endocytic recycling compartment. Subsequently, DAT may undergo exocytosis back to the plasma membrane. For comparison, the constitutive recycling of the transferrin receptor is also depicted.

involved in transporter trafficking? Preliminary data from our laboratory (our unpublished results) and recent observations from Apparsundaram et al. (1998a) and Beckman et al. (1999) suggest that DAT, NET, and GABA transporters, respectively, undergo downregulation in response to activation of muscarinic cholinergic receptors. Recent reports support the hypothesis that muscarinic downregulation of DATs is also likely to occur in the brain. For example, elevated extracellular DA concentrations in vivo after administration of muscarinic agonists have been detected in rat striatum (Smolders et al., 1997) and VTA (Westerink et al., 1998) and could be attributed to DAT downregulation. Future studies examining recovery from downregulation should shed light on possible DAT recycling and the molecular mechanisms underlying DAT trafficking.

How does DAT membrane trafficking fit into our conception of general membrane trafficking? As illustrated in Figure 10, the majority of proteins that undergo endocytic trafficking are initially internalized to the rab5-positive sorting endosome. Once in the sorting endosome, proteins can be targeted to the late endosome-lysosome pathway, as is the EGF receptor, or enter the ERC and undergo exocytosis back to the cell surface, as does the transferrin receptor. Fitting our data into the known model of endocytic trafficking, we hypothesize that DAT downregulationtrafficking could occur in the following manner (Fig. 10). Activation of PKC, possibly via a G-protein-coupled receptor, such as the muscarinics, results in an increased accumulation of DAT in the recycling endosome, consistent with the hypothesis that DAT undergoes endocytic trafficking, and possibly recycling, after activation of PKC. Effectors of PKC that affect DAT trafficking have not, as yet, been identified and should reveal the molecular events responsible for DAT sequestration.

In conclusion, we have characterized DAT regulation and trafficking in stably transfected PC12 cells. We have demon- 
strated that DAT undergoes endocytosis in response to $\beta \mathrm{PMA}-$ induced PKC activation and have identified the endocytic pathway through which DAT traffics in both steady-state and regulated conditions. These results represent the first direct description of the trafficking pathways used by a $\mathrm{Na}^{+} / \mathrm{Cl}^{-}$dependent transporter and identify the specific endocytic compartment harboring DAT. The initial identification of DAT trafficking and endocytosis in a neuroendocrine cell line forms the basis for future studies investigating the mechanisms underlying DAT trafficking.

\section{REFERENCES}

Ahn J, Mundig O, Muth TR, Rudnick G, Caplan MJ (1996) Polarized expression of GABA transporters in Madin-Darby canine kidney cells and cultured hippocampal neurons. J Biol Chem 271:6917-6924.

Amara SG, Kuhar MJ (1993) Neurotransmitter transporters: recent progress. Annu Rev Neurosci 16:73-93.

Apparsundaram S, Galli A, DeFelice LJ, Hartzell HC, Blakely RD (1998a) Acute regulation of norepinephrine transport. I. Protein kinase $\mathrm{C}$-linked muscarinic receptors influence transport capacity and transporter density in SK-N-SH cells. J Pharmacol Exp Ther 287:733-743.

Apparsundaram S, Schroeter S, Giovanetti E, Blakely RD (1998b) Acute regulation of norepinephrine transport. II. PKC-modulated surface expression of human norepinephrine transporter proteins. J Pharmacol Exp Ther 287:744-751.

Barker EL, Blakely RD (1995) Norepinephrine and serotonin transporters: molecular targets of antidepressant drugs. In: Psychopharmacology: the fourth generation of progress (Bloom F, Kupfer D, eds), pp 321333. New York: Raven.

Batchelor M, Schenk JO (1998) Protein kinase A activity may kinetically upregulate the striatal transporter for dopamine. J Neurosci 18:10304-10309.

Beckman ML, Quick MW (1998) Neurotransmitter transporters: regulators of function and functional regulation. J Membr Biol 164:1-10.

Beckman ML, Bernstein EM, Quick MW (1998) Protein kinase C regulates the interaction between a GABA transporter and syntaxin 1A. J Neurosci 18:6103-6112.

Beckman ML, Bernstein EM, Quick MW (1999) Multiple G-proteincoupled receptors inititate protein kinase $\mathrm{C}$ redistribution of GABA transporters in hippocampal neurons. J Neurosci 19:RC9, 1-6.

Blakely RD, Ramamoorthy S, Schroeter S, Qian Y, Apparsundaram S, Galli A, DeFelice LJ (1998) Regulated phosphorylation and trafficking of antidepressant-sensitive serotonin transport proteins. Biol Psychiatry $44: 169-178$.

Cao TT, Mays RW, von Zastrow M (1998) Regulated endocytosis of G-protein-coupled receptors by a biochemically and functionally distinct subpopulation of clathrin-coated pits. J Biol Chem 273:24592-24602.

Clague MJ (1998) Molecular aspects of the endocytic pathway. Biochem J 336:271-282.

Clift-O'Grady L, Linstedt AD, Lowe AW, Grote E, Kelly RB (1990) Biogenesis of synaptic vesicle-like structures in a pheochromocytoma cell line PC-12. J Cell Biol 110:1693-1703.

Copeland BJ, Vogelsberg V, Neff NH, Hadjiconstantinou M (1996) Protein kinase $C$ activators decrease dopamine uptake into striatal synaptosomes. J Pharmacol Exp Ther 277:1527-1532.

Corey JL, Davidson N, Lester HA, Brecha N, Quick MW (1994) Protein kinase $\mathrm{C}$ modulates the activity of a cloned $\gamma$-aminobutyric acid transporter expressed in Xenopus oocytes via regulated subcellular redistribution of the transporter. J Biol Chem 269:14759-14767.

Dunn KW, McGraw TE, Maxfield FR (1989) Iterative fractionation of recycling receptors from lysosomally destined ligands in an early sorting endosome. J Cell Biol 109:3303-3314.

Grace AA (1995) The tonic/phasic model of dopamine system regulation: its relevance for understanding how stimulant abuse can alter basal ganglia function. Drug Alcohol Depend 37:111-129.

Grimes ML, Zhou J, Beattie EC, Yuen EC, Hall DE, Valletta JS, Topp KS, LaVail JH, Bunnett NW, Mobley WC (1996) Endocytosis of activated TrkA: evidence that nerve growth factor induces formation of signaling endosomes. J Neurosci 16:7950-7964.

Grimes ML, Beattie E, Mobley WC (1997) A signaling organelle containing the nerve growth factor-activated receptor tyrosine kinase, TrkA. Proc Natl Acad Sci USA 94:9909-9914.

Gu HH, Ahn J, Caplan MJ, Blakely RD, Levey AI, Rudnick G (1996) Cell-specific sorting of biogenic amine transporters expressed in epithelial cells. J Biol Chem 271:18100-18106.

Hersch SM, Yi H, Heilman CJ, Edwards RH, Levey AI (1997) Subcellular localization and molecular topology of the dopamine transporter in the striatum and substantia nigra. J Comp Neurol 388:211-227.

Horn AS (1990) Dopamine uptake: a review of progress in the last decade. Prog Neurobiol 34:387-400.

Huff RA, Vaughan RA, Kuhar MJ, Uhl GR (1997) Phorbol esters increase dopamine transporter phosphorylation and decrease transport Vmax. J Neurochem 68:225-232.

Jones SR, Gainetdinov RR, Jaber M, Giros B, Wightman RM, Caron MG (1998) Profound neuronal plasticity in response to inactivation of the dopamine transporter. Proc Natl Acad Sci USA 95:4029-4034.

Langer SZ (1997) 25 years since the discovery of presynaptic receptors: present knowledge and future perspectives. Trends Pharmacol Sci 18:95-99.

Lee FJS, Pristupa ZB, Ciliax BJ, Levey AI, Niznik HB (1996) The dopamine transporter carboxyl-terminal tail. J Biol Chem 271:20885-20894.

Lissin DV, Carroll RC, Nicoll RA, Malenka RC, von Zastrow M (1999) Rapid, activation-induced redistribution of ionotropic glutamate receptors in cultured hippocampal neurons. J Neurosci 19:1263-1272.

McGraw TE, Greenfield L, Maxfield FR (1987) Functional expression of the human transferrin receptor cDNA in Chinese hamster ovary cells deficient in endogenous transferrin recpetor. J Cell Biol 105:207-214.

Melikian HE, McDonald JK, Gu H, Rudnick G, Moore KR, Blakely RD (1994) Human norepinephrine transporter: Biosynthetic studies using a site directed polyclonal antibody. J Biol Chem 269:12290-12297.

Mellman I (1996) Endocytosis and molecular sorting. Annu Rev Cell Dev Biol 12:575-625.

Nagatsu T, Stjarne L (1998) Catecholamine synthesis and release. Overview. Adv Pharmacol 42:1-14.

Nelson $\mathrm{N}$ (1998) The family of $\mathrm{Na}^{+} / \mathrm{Cl}^{-}$neurotransmitter transporters. J Neurochem 71:1785-1803.

Nirenberg MJ, Vaughan RA, Uhl GR, Kuhar MJ, Pickel VM (1996) The dopamine transporter is localized to dendritic and axonal plasma membranes of nigrostriatal dopaminergic neurons. J Neurosci 16:436-447.

Nirenberg MJ, Chan J, Vaughan RA, Uhl GR, Kuhar MJ, Pickel VM (1997) Immunogold localization of the dopamine transporter: an ultrastructural study of the rat ventral tegmental area. J Neurosci 17:5255-5262.

Pristupa ZB, McConkey F, Liu F, Man HY, Lee FJ, Wang YT, Niznik HB (1998) Protein kinase-mediated bidirectional trafficking and functional regulation of the human dopamine transporter. Synapse 30:79-87.

Qian Y, Galli A, Ramamoorthy S, Risso S, DeFelice LJ, Blakely RD (1997) Protein kinase C activation regulates human serotonin transporters in HEK-293 cells via altered cell surface expression. J Neurosci 17:45-57.

Quick MW, Corey JL, Davidson N, Lester HA (1997) Second messengers, trafficking-related proteins, and amino acid residues that contribute to the functional regulation of the rat brain GABA transporter GAT1. J Neurosci 17:2967-2979.

Ramamoorthy S, Giovanetti E, Qian Y, Blakely RD (1998) Phosphorylation and regulation of antidepressant-sensitive serotonin transporters. J Biol Chem 273:2458-2466.

Renick SE, Kleven DT, Chan J, Stenius K, Milner TA, Pickel VM, Fremeau Jr RT (1999) The mammalian brain high-affinity L-proline transporter is enriched preferentially in synaptic vesicles in a subpopulation of excitatory nerve terminal in rat forebrain. J Neurosci 19:21-33.

Sakai N, Sasaki K, Nakashita M, Honda S, Ikegake N, Saito N (1997) Modulation of serotonin transporter activity by a protein kinase $\mathrm{C}$ activator and an inhibitor of type 1 and $2 \mathrm{~A}$ serine/threonine phosphatases. J Neurochem 68:2618-2624.

Sato K, Betz H, Schloss P (1995) The recombinant GABA transporter GAT1 is downregulated upon activation of protein kinase C. FEBS Lett 375:99-102.

Schmidt A, Hannah MJ, Huttner WB (1997) Synaptic-like microvesiclesof neuroendocrine cells originate from a novel compartment that is continuous with the plasma membrane and devoid of transferrin receptor. J Cell Biol 137:445-458. 
Smolders I, Bogaert L, Ebinger G, Michotte Y (1997) Muscarinic modulation of striatal dopamine, glutamate, and GABA release, as measured with in vivo microdialysis. J Neurochem 68:1942-1948.

Sorkin A (1998) Endocytosis and intracellular sorting of receptor tyrosine kinases. Front Biosci 3:d729-d738.

Uchida J, Kiuchi Y, Yura OM, Oguchi K (1998) Ca(2+)-dependent enhancement of $[3 \mathrm{H}]$ noradrenaline uptake in $\mathrm{PC} 12$ cells through calmodulin-dependent kinases. Brain Res 809:155-164.

Vaughan RA, Huff RA, Uhl GR, Kuhar MJ (1997) Protein kinase $\mathrm{C}$-mediated phosphorylation and functional regulation of dopamine transporters in striatal synaptosomes. J Biol Chem 272:15541-15546.

Vickery RG, von Zastrow M (1999) Distinct dynamin-dependent and -independent mechanisms target structurally homologous dopamine receptors to different endocytic membranes. J Cell Biol 144:31-43.

Westerink BH, Enroco P, Feimann J, de Vries JB (1998) The pharmacology of mesocortical dopamine neurons: a dual-probe microdialysis study in the ventral tegmental area and prefrontal cortex of the rat brain. J Pharmacol Exp Ther 285:143-154.

Zhang L, Coffey LL, Reith ME (1997) Regulation of the functional activity of the human dopamine transporter by protein kinase $\mathrm{C}$. Biochem Pharmacol 53:677-688.

Zhu S-J, Kavanaugh MP, Sonders MS, Amara SG, Zahniser NR (1997) Activation of protein kinase $\mathrm{C}$ inhibits uptake, currents and binding associated with the human dopamine transporter expressed in Xenopus oocytes. J Pharmacol Exp Ther 282:1358-1365. 